\title{
FUNDAMENTOS BIOQUÍMICOS DA HF.RFDITARIEDADE - I NATUREZA DO MATERIAL GENÉTICO $\left({ }^{*}\right)$
}

\author{
Paulo A. Otto $(* *)$
}

\section{INTRODUÇÃO}

O presente trabalho ccnstitui uma revisão sumária dos principais aspectos bioquímicos ligados diretamente à Genética e está moldado sôbre uma série de palestras proferidas pelo autor no serviço de Pesquisas e Experimentação do Instituto Nacional do Câncer (Seção de Imunologia e Seleção de Animais de Laboratório) durante os meses de agôsto e setembro de 1966 .

Essencialmente, no estudo dos fundamentos bioquímicos da hereditariedade, devem ser abordados três aspectos principais, quais sejam:

1) A natureza da substância responsável pelo aparecimentc e pela transmissão dos caracteres biológicos (estrutura e função do DNA ou material hereditário);

2) O modo de transmissão dêsse material de um organismo a outro:

a) A duplicaçāo do DNA;

b) As mutações a nível molecular;
3) O modc de ação dêsse material, isto é, como o DNA promove o aparecimento das características biológicas:

a) As enzimas;

b) O contrôle qualitativo da sintese protêica;

c) $O$ contrôle quantitativo da sintese protêica.

F. fornecida, no fim de cada uma das seis seções $(1,2 a, 2 b, 3 a, 3 b$ e 3c), uma bibliografia de referências, contendo obras ou artigos de revisão geral e artigos originais selecionados; no final do trabalho é dada uma bibliografia geral; tanto uma como outra servirão aos interessados para um aprofundamento teórico, complementando os diversos assuntos expostos.

Este trabalho é para M.M.B.: "Also prangt die Natur in hoher, voller Erscheinung, und sie zeiget, gereint, Glieder an Glieder gestuft”. (Gcethe).

(*) - Trabalho do Serviço de Pesquisas e Experimentação do Instituto Nacional do Câncer - Seção de Imunologia e Seleção de Animais de Laboratório (Chefe: Dr. Sylvio Thales Tôrres). (**) - Professor Conferencista de Genética da Faculdade de Ciências Médicas da U.E.G. - Médico do 


\section{1) NATUREZA DO MATERIAL HEREDITÁRIO}

Inúmeras experiências realizadas de to anos para cá vêm demonstrando cabalmente que a substância responsável pelo aparecimento e pela transmissão dos caracteres biológicos na quase totalidade dos organismos vivos é o ácido desoxirribonuclêico (DNA). Duas experiências que objetivam admiràvelmente êsse fato são as de Griffith e de Hershey \& Chase.

Em 1928, Griffith descobriu que uma mistura de pneumocccos (Diplococcus algum constituinte, ainda ativo, das células virulentas mortas. Em 1944 Avery. MacLeod \& Mc Carthy identificaram o "princípio da transformação bacteriana" come sendo o ácido desoxirribonuclêico.

Em 1952, Hershey \& Chase realizaram a sua famosa experiência: parasitaram bactérias Escherichia coli com bacteriófagos específicos $\mathrm{T}_{\text {: }}$ marcados com $\mathrm{P}^{* 2}$ e $\mathrm{S}$. Como o bacteriófago $T_{2}$ só possui DNA (cêrca de $40 \%$ ) e cápsula protêica (cêrca de $60 \%$ ), o fósforo marcado estava integrado na molécula do DNA e o enxôfre radioativo na molécula da proteína. An-

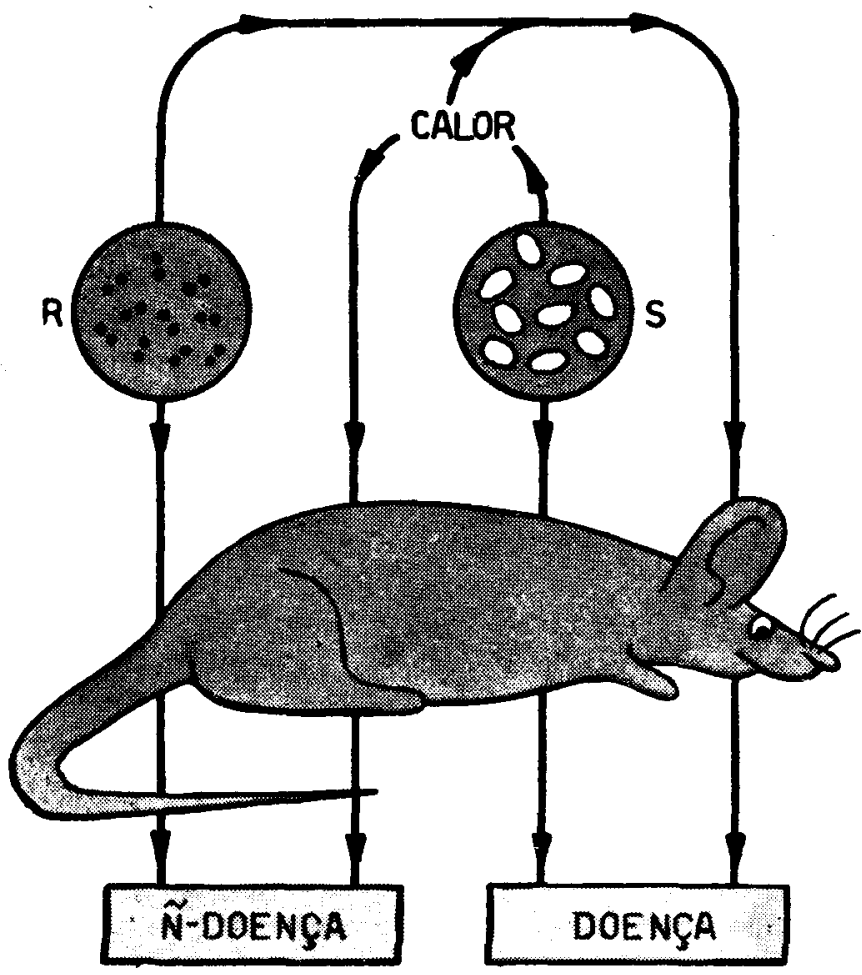

Fig. 1

pneumoniae, acapsulados (avirulentos) $R$ vivos e capsulados (virulentos) $\mathbf{S}$ mortos pelo calor causava uma septicemia fatal quando inoculada em camundongos (fig. 1).

Evidentemente, a transformação, no organismo dos camundongos, dos pneumococos acapsulados em pneumococos virulentos capsulados deveria ser causada por tes de ocorrer a lise bacteriana, o meio contendo as bactérias infectadas foi submetido a uma agitação com liquidificador ("waring blendor") e, após, a uma centrifugação. Por meio de contadores GeigerMüller foi determinado que no sobrenadante (que deveria conter os fagos) só havia pràticamente $\mathbf{S}^{* 5}$, enquanto que pràticamente todo o $\mathrm{P}^{32}$ estava no sedimento (bactérias). Embora a experiência tenha 


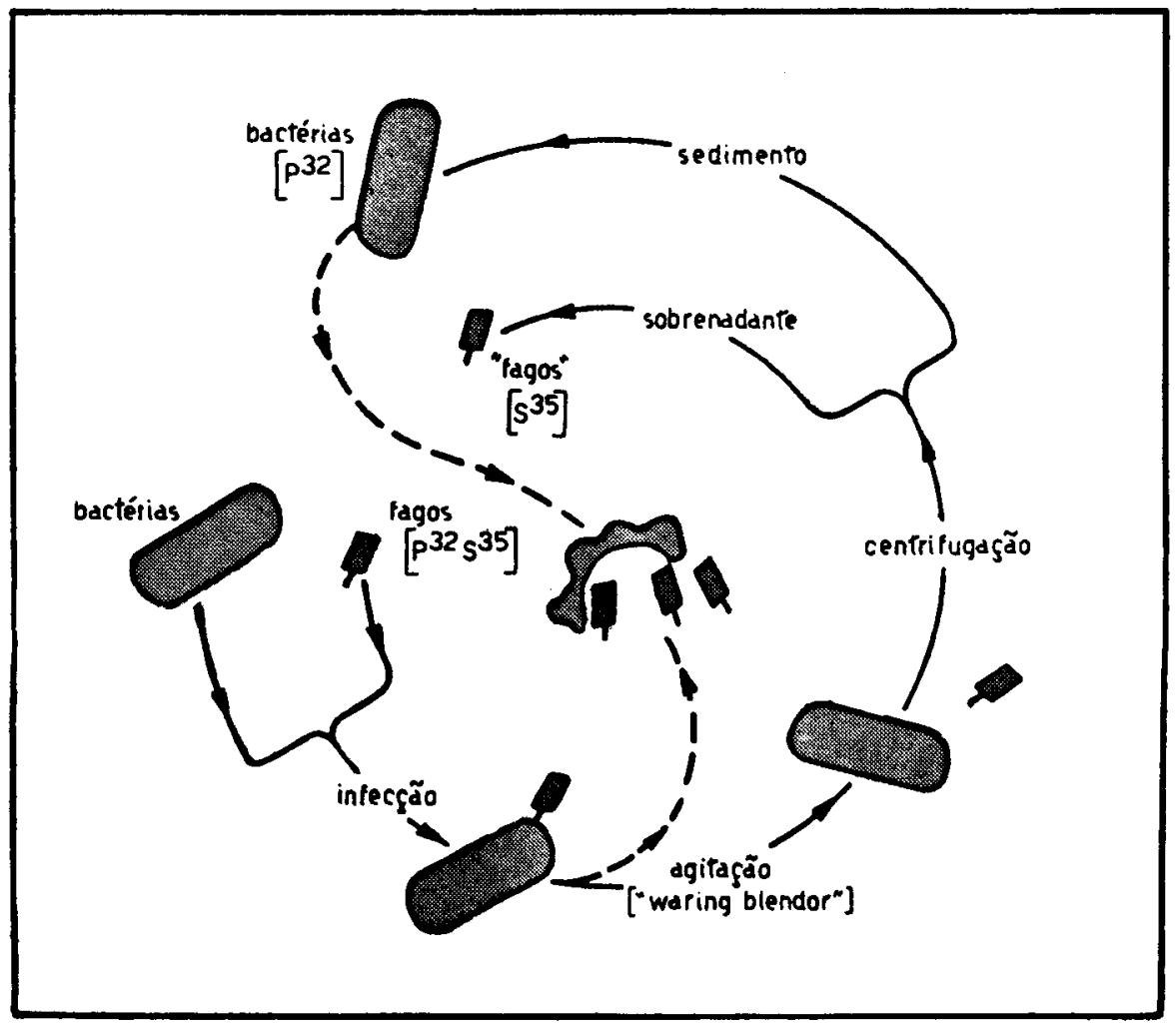

Fig. 2

sido realizada em duas etapas (infecção de bactérias com fagcs $\mathrm{P}^{\mathrm{*}} \mathrm{e}$ infecção de bactérias com fagos $\mathbf{S}^{35}$ ), ela pode ser representada pelo esquema da fig. 2 .

Nesse esquema, a primeira linha interrompida da seqüência indica a lise bacteriana (com o aparecimerito de novas paitículas de fagos) que ocorre normalmente e antes da qual foram realizadas a agitação e a centrifugação descritas. A palavra "fagos" do fim da seqüência está entre aspas porque èstes já não são capazes de se replicarem (falta o DNA). A última linha interrompida da sequência indica que as bactérias infectadas com $P^{32}$ (DNA dos fagos) são capazes de lisarem, dando origem a novas partículas infectantes de bacteriófagos. Com esta experiência ficou provado que o virus bacteriano $T_{2}$ reproduz-se exclusivamente às custas do seu DNA.

A hidrólíse do ácido desoxirribonuclêico fornece as seguintes substâncias (fig. 3):

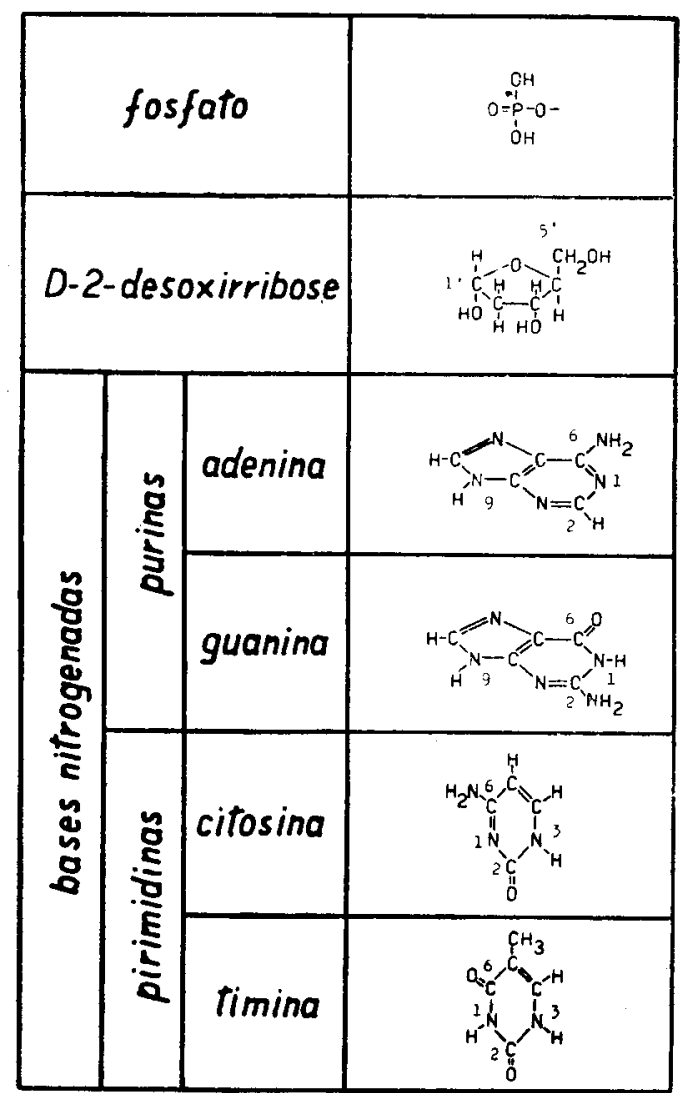

Fig. 3 
Chargaff, em 1951, analisando o DNA do esperma do salmão, conseguiu determinar que na molécula dessa substância havia uma equimolaridade na concentração das bases nitrogenadas purínicas e pirimidínicas:

$\begin{array}{cc}\text { A } & 0,280 \pm 0,005 \\ \text { G } & 0,196 \pm 0,004 \\ \text { C } & 0,192 \pm 0,006 \\ \text { T } & 0,274 \pm 0,005\end{array}$

relação $A / G$

1,43

relação $\mathrm{T} / \mathrm{C}$

relação $\mathrm{A} / \mathrm{T}$

relação $\mathrm{G} / \mathrm{C}$

relação $(A+G) /(T+C)$

1,43

$1,02 \cong 1$

$1,02 \cong 1$

$1,02 \simeq 1$

Embora as relações $\mathrm{A} / \mathrm{T}, \mathrm{G} / \mathrm{C}$ e $\mathrm{Pu} / \mathrm{Py}$ se mantenham constantes e iguais à unidade qualquer que seja a fonte do DNA, as relaçōes $\mathbf{A} / \mathbf{G}, \mathrm{T} / \mathrm{C}$ e $(\mathbf{A}+\mathbf{T}) /(\mathbf{G}+\mathbf{C})$ variam e seriam características para cada espécie animal ou vegetal:

\begin{tabular}{|c|c|c|c|c|c|}
\hline fonte de DNA & $\overline{\mathbf{A}+\mathbf{T}}$ & A & $\mathrm{T}$ & G & $\mathrm{C}$ \\
\hline bacteriófago lambda & 1,06 & 25,7 & 25,7 & 24,4 & 24,2 \\
\hline bacteriófago $\mathrm{T}_{1}$ & 1,08 & 27,0 & 25,0 & 23,0 & 25,0 \\
\hline bacteriófago $\mathrm{T}_{2}$ & 1,86 & 32,5 & 32,5 & 18,2 & 16,8 \\
\hline bacteriófago $\mathrm{T}_{4}$ & 1,92 & 32,3 & 33,3 & 18,1 & 16,1 \\
\hline bacteriófago $T_{6}$ & 1,92 & 32,4 & 33,4 & 17,7 & 16,5 \\
\hline bacteriófago $\mathbf{T}_{7}$ & 1,08 & 26,0 & 26,0 & 24,0 & 24,0 \\
\hline Bos taurus, timo & 1,27 & 28,2 & 27,8 & 21,5 & 22,5 \\
\hline Bos taurus, esperma & 1,26 & 28,7 & 27,2 & 22,2 & 22,0 \\
\hline Clostridium perfringens & 2,24 & 34,1 & 35,0 & 15,8 & 15,1 \\
\hline Escherichia coli & 0,92 & 23,9 & 23,9 & 26,0 & 26,2 \\
\hline Gallus domesticus & 1,38 & 28,8 & 29,2 & 20,5 & 21,5 \\
\hline Homo sapiens, baço & 1,51 & 29,9 & 29,8 & 19,5 & 20,1 \\
\hline Homo sapiens, fígado & 1,53 & 30,3 & 30,3 & 19,5 & 19,0 \\
\hline Homo sapiens, esperma & 1,66 & 31,0 & 31,5 & 19,1 & 18,4 \\
\hline Mycobacterium phlei & 0,48 & 16,2 & 16,4 & 33,7 & 33,7 \\
\hline Mycobacteriurn tuberculosis & 0,48 & 16,5 & 16,0 & 34,2 & $33, \mathbf{2}$ \\
\hline Pseudomonas aeruginosa & 0,49 & 16,8 & 16,2 & 33,0 & 34,0 \\
\hline Proteus vulgaris & 1,47 & 30,1 & 29,4 & 19,8 & 20,7 \\
\hline Saccharomyces cerevisiae & 1,79 & 31,3 & 32,9 & 18,7 & 17,1 \\
\hline Scenedesmus caudatus & 0,64 & 20,2 & 18,8 & 30,8 & 30,2 \\
\hline Staphylococcus aureus & 1,88 & 32,3 & 33,0 & 17,3 & 17,4 \\
\hline Streptomyces griseus & 0,37 & 13,4 & 13,4 & 36,1 & 37,1 \\
\hline Triticum vulgare & 1,14 & 26,9 & 26,5 & 23,2 & 23,5 \\
\hline Vírus da vaccinia & 1,46 & 29,5 & 29,9 & 20,6 & 20,2 \\
\hline
\end{tabular}

Estudos de difração com raios-X, iniciados por Furberg e continuados (e pràticamente concluídos) por Wilkins e outros pesquisadores, demonstrando que a molécula do DNA possui uma estrutura espacial heliccidal e o achado da Escola de Chargaff (equimolaridade na concentração das purinas e primidinas) levaran Watson \& Crick, em 1953, à proposição de um modêlo estrutural para o DNA, modêlo êsse que até hoje vem resistindo às críticas.
A estrutura provável do ácido desoxirribonuclêico consiste fundamentalmente numa hélice formada por duas hemimacromoléculas "complementares": do is filamentos de açúcar-fcsfato $\left(R^{\prime} P\right)^{n}$, a cada molécula de açúcar se prendendo uma base nitrogenada ( $A, C, G$ ou $\mathrm{T}$ ); as bases prêsas a um dos filamentos estão pareadas com as bases do outro filamento mediante ligações de baixo potencial energético (pontes de hiđrogênio cu ligações de ressonância de Van der Waals) que se es- 


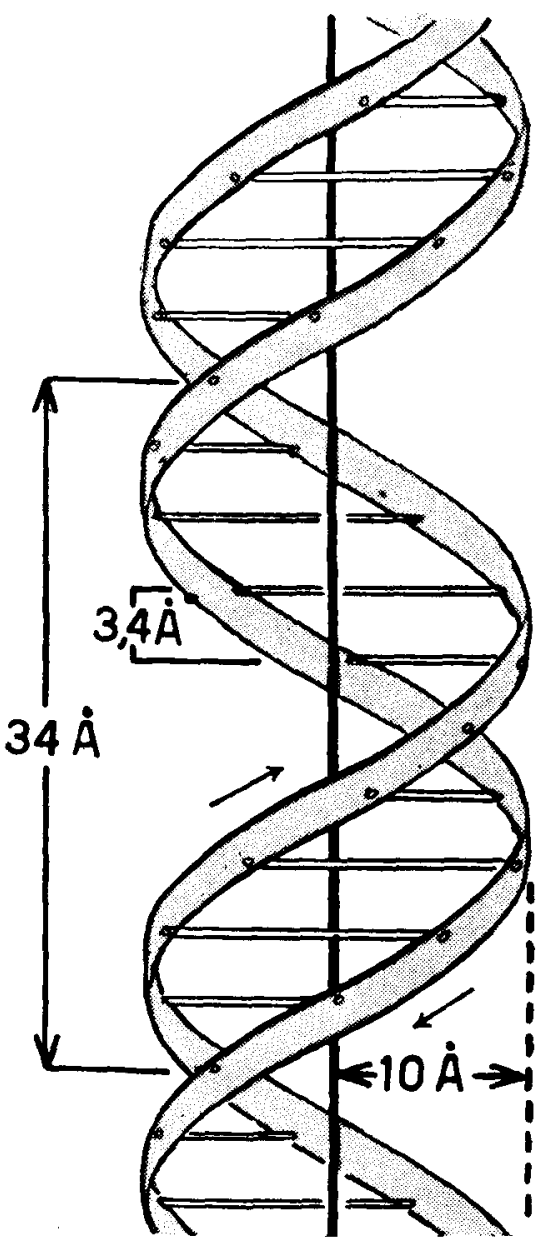

Fig. 4

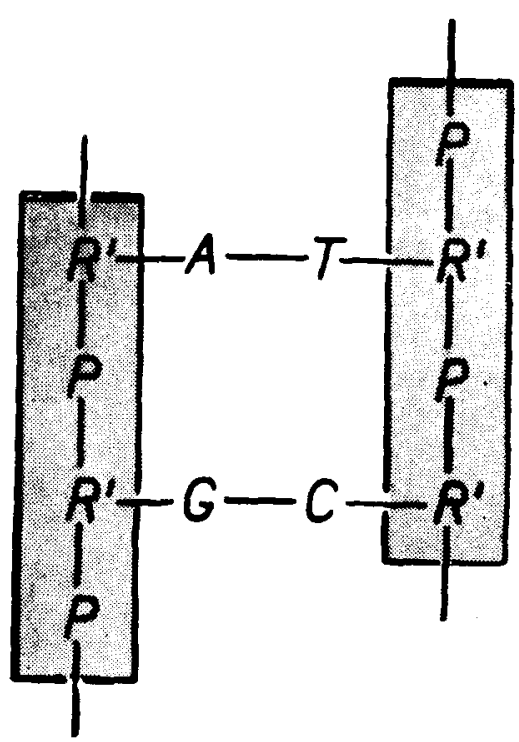

tabelecem entre as bases nitrogenadas com grupamentos amínicos ligados ao átomo de carbono de posição 6 (adenina e guoanina) e com grupamentos cetônicos de posição 6 (timina e citosina), de tal modo que só são possíveis os pareamentos entre adenina e timina e entre guanina e citosina. Como PR'A, PR'C, PR'G e PR'T são 5'-nucleotídios( respectivamente ácido 5'-desoxiadenílicc, ácido 5'-desoxicitidilico, ácido 5'-desoxiguanílico e ácido 5'-desoxitimidílico), o ácido desoxirribonuclêico é considerado um polidesoxirribonucleotidio de estrutura dupla. (Fig. 4).

Cada hemimolécula pode ser representada pela fórmula $\left(P R^{\prime} X\right)$ ", onde $X \dot{e}$ qualquer uma das bases nitrogenadas (A, C, G, ou T). (Fig. 5).

No esquema da página seguinte (Fig. 6) está representada uma porção hipotética da cadeia estirada do DNA.

Na parte superior do desenho estão representados dois pares de resíduos de nucleotídios "complementares" segundo uma convenção arbitrária que será observada em alguns esquemas do presente trabalho.

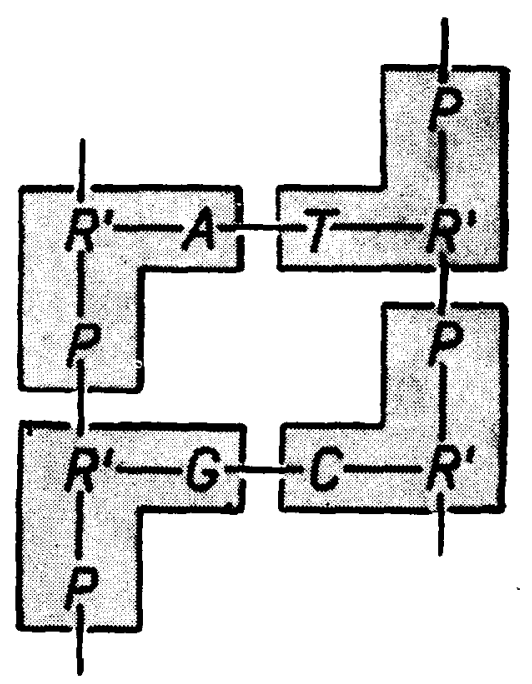




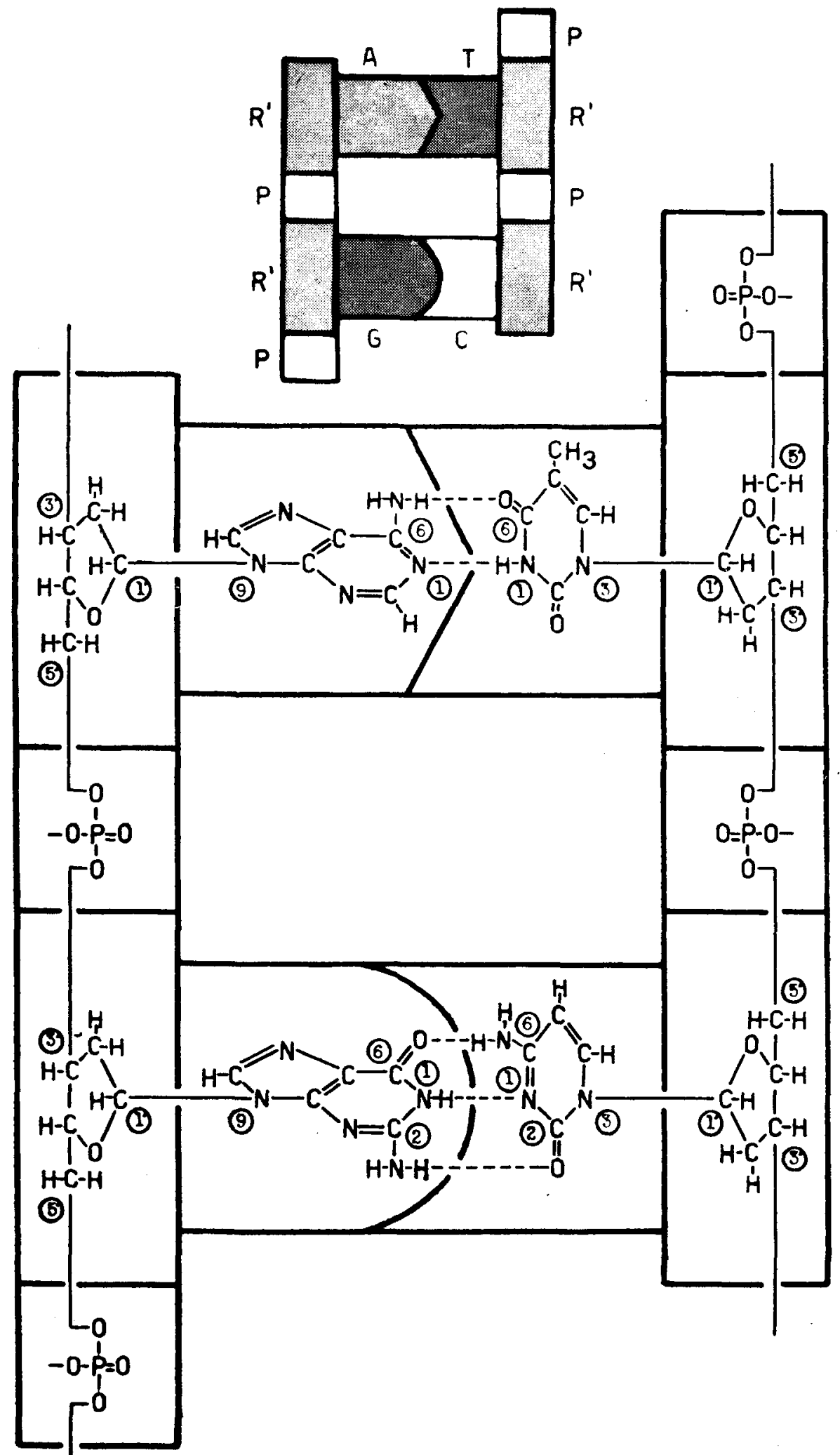

Fig. 6 
Na parte inferior tem-se uma ampliação do esquema superior, mostrando a estrutura química do DNA. Os fosfatos unem-se às moléculas de pentose pelos atomos de carbono $3^{\prime}$ e 5'; as pentoses ligam-se ao nitrogênio da posição 9 dos anéis purínicos cu ao nitrogênio da posição 3 dos anéis pirimidínicos através de seu carbono 1'. Finalmente, as purinas parecem-se com as pirimidinas mediante ligações de ressonância que se estabelecem entre: átomo de hidrogênio do grupamento amínico ligado ao carbono 6 da adenina e átomo de oxigènio do grupamento cetônico 6 da timina; átomo de nitrogênio de posição $1 \mathrm{da}$ adenina e átomo de hidrogênio do grupamento imínico 1 da timina; átomo de oxigênio do grupamento cetônico 6 da guanina e átomo de hidrogênio do grupamento amínico ligado ao átomo de carbono 6 da citcsina; átomo de hidrogênio do grupamento imínico $1 \mathrm{da}$ guanina e átomo de nitrogênio 1 da citosina; átomo de hidrogênio do grupamento amínico ligado ao carbono 2 da guanina $e$ átomo de cxigênio do grupamento cetónico 2 da citosina.
O raio da molécula do ácido desoxirribonuslêico é da ordem de $10 \mathrm{~A}^{\circ} \mathrm{e}$ a distância entre dois pares de bases subseqüentes equivale a $3,4 \mathrm{~A}^{\circ}$; um passo completo da hélice contém 10 pares de resíduos de nucleotídios. O DNA do bacteriofago $\mathbf{T}$ de Escherichia coli possui um comprimento de 47 microns, um pêso molecular de $1,3 \times 10^{*}$, equivalendo a uma seqüência de $2,0 \times 10^{5}$ pares de resíauos de desoxirribonuclectídios. O DNA contido num complemento cromossomial diplóide (8 cromossomas) da môsca Drosophila melanogaster teria um comprimento total de $2,7 \mathrm{~cm}$, equivalendo a uma seqüência de $2,5 \times 10^{\circ}$ pares de resíduos de desoxirribonucleotídios.

Apesar da aparente pequena capacidade de armazenar informações, por causa de sua composição um tanto pobre e monótona, admite-se que a seqüência linear dos resíduos de nucleotidios (ou, como êstes diferem entre si apenas pelas bases nitrogenadas, a seqüência destas) na molécula do DNA (estrutura primária do ácido desoxirribonuclêico) é o que condiciona o aparecimentc dos caracteres biológicos hereditários dos organismos.

\section{BIBLIOGRAFIA}

1 - AVERY, O. T., MACLEOD, C. M. MCCART'HY, M. - "Studies on the Chemical Nature of the Substance Inducing Transformation of Pneumococcal Types", J. Exper. Med., 79: 237-158, 1944

2 - BRESCH, C. - "Klassische und Molekulare Genetik", Springer Verlag, Berlin, 1965

3 - CHARGAFF, E., LIPSHITZ, R., GREEN, C., HODES., M. E. - "The Composition of the Desoxyribonucleic Acid of Salmon Sperm", J. Biol. Chem., 192: 223-230, 1951.

4-GRIFFITH, F. - "The Significance of Pneumococcal Types", J. Hyg., 27: $113-159,1928$

5 - GURGEL, J. T. A. - "Genética de Microrganismos", in Pavan, C. Cunha, A.B., "Elementos de Genética", Companhia Eđitôra Nacional, São Paulo, 1966, Pp. 67-93.

6 - HERSHEY, A.D., CHASE, M.D. "Independent Functions of Viral Protein and Nucleic Acid in Growth of Bacteriophage", J. Gen. Physiol., 36: 39-56, 1952

7 - HERSKOWITZ, I. H. - "Genetics", Little, Brown \& Co., Boston, 1965.
8 - HOFSCHNEIUER, P. H. - "La Herencia a Nivel Molecular", in Documenta Geigy, "Genética y Medicina", Basel, 1964, Pp. 2-4.

9 - LARA, F. J. S., MIRANDA, M. "Bases Quimicas da Hereditariedade". in Pavan, C., Cunha, A.B., "Elementos de Genética", Companhia Editôra Nacional, São Paulo, 1966. Pp. 18 36

10 - MEDOFF, G., SWARTZ, M.N. "DNA - Structure and Enzymatic Synthesis", New Eng. J. Med., 276: 728-737, 1967.

11 - SILVER, S. - "Molecular Genetics of Bacteria and Bacteriophages". Progr. Biophys. Molec. Biol., 16: 193-240, 1966.

12 - STAHL, F. W. - "The Mechanics of Inheritance", Prentice-Hall, Inc., Englewood Cliffs, 1965.

13 - WATSON, J. D., CRICK, F. H. C. "A Structure for Deoxyribose Nucleic Acid", Nature, 171: 737-738, 1953.

14 - WILKINS, M. H. F., STCKES, A. R. WILSON, H.R. - "Molecular Structure of Deoxypentose Nucleic Acids", Nature, 171: 738-740, 1953. 